\title{
The Use of Technology in Language Classrooms in Libya
}

\author{
Ibrahim Abukhattala
}

\begin{abstract}
There is an increasing pressure exercised by the advancements of technology on education. Recently the use of technology for teaching has become an integral part of successful learning and teaching languages in many parts of the world. Although education policy makers in Libya claim that computers and related internet technologies represent important educational innovations, they are not widely used in Libyan foreign language classrooms. As many researchers suggest, the successful implementation of educational technologies depends mainly on the attitudes of teachers, who eventually decide on whether to integrate them or not and on how they are utilized in the teaching process.

This qualitative research study was carried out to investigate English language teachers' readiness and willingness to integrate technology in some high and secondary schools in Misurata, Libya. Twelve in-service English language teachers participated in this study. Data were collected through structured and semi structured interviews. As revealed in the interviews, three themes have emerged which are, (a) Understanding of technology, (b) Types of technology and (c) Cultural and traditional styles of learning and teaching. Participants complained about lack of funding, scarcity of technology in schools and paucity of proper training to use technology. However, all the participants were willing to use technology to teach English as a foreign language. The paper concludes with implications and important suggestions and recommendations for education policy makers and directions for further research. Although this study was conducted in Libya, findings and recommendations can be useful in other educational contexts.
\end{abstract}

Index Terms - Technology, language classrooms, foreign countries, Libya.

\section{INTRODUCTION}

In many countries the introduction of Technology into language classrooms has been praised as the necessary course of action for the qualitative improvement of teaching and learning methodology. Introduction of technology in school is considered a necessity premised on pedagogical rationales. Researchers have suggested that a crucial factor for successful technology integration into the classroom is the teacher [1], because what directly determines the instruction that takes place behind the classroom door is the teacher rather than external educational agenda or requirements. Researchers have found that teacher beliefs play a critical role in transforming teachers' technology integration into more constructivist practices [2]. Therefore, the relations between teachers' beliefs and teachers' practices should help to shed light on how teachers make technology-integration decisions.

Manuscript received September 30, 2014; revised December 10, 2014.

Ibrahim Abukhattala is with the Faculty of Arts, University of Misurata, Libya (e-mail: ibrahim.abukhattala@mail.mcgill.ca).
In Libyan foreign language classrooms, the overall picture seems to be that introduction of technology, although long awaited and strongly supported, encounters significant problems related to the attitudes of the people who are responsible for its use in the classroom. This research study attempts understand the attitudes of teachers of English towards the use of technology at certain schools in Misurata city. It tries to find out whether the teachers are effectivelyimplementing technology in the classrooms and to identify obstacles to technology implementation and provide reliable information to aid decision makers to take appropriate measures.

\section{English LANGUAGE TEACHING IN LIBYA}

Libya does not enjoy the ethnolinguistic diversity that other countries in the region have, with $98 \%$ of its population speaking Arabic. A foreign (rather than second) language in Libya, English is taught as a compulsory core subject from grades 5-12. Though few people use it in their personal lives, the country depends on it for both internal and international business, and there is no doubt about its importance in job markets, business, industry and government, with workers increasingly expected to develop skills in English. Proficiency in English is widely seen as a precondition leading to economic, social and educational opportunities, and providing access to material resources. Because of the importance accorded to English and the consistently escalating demands for English proficiency.

At all levels of education, the grammar-translation method is still the norm of ELT in Libya and considerable friction between policy-level expectations and actual practice can be felt by practitioners. Such practice involves a heavy emphasis on grammatical rules, vocabulary memorisation and translation of (mostly decontextualised) sentences. English lessons are conducted solely in Arabic, with little use of English. Until recently, the secondary English textbook was mainly a collection grammatical rules book in which grammar items were presented structurally with almost no interactive exercises. The emphasis has been on grammar, encouraging students to learn the language but not how to use it in a given context. While examinations assessed grammatical knowledge, along with writing skills, speaking and listening skills were neither a focus of classroom teaching, nor were they tested in the exam.

The highly centralized, national examination system is a powerful impediment to change in educational innovation. Libyan English teachers have as their primary responsibility the duty of preparing their students to pass public examinations. Tests and examinations are an important part of English teaching. They are frequently conducted in the forms of quizzes, midterm tests and finals. Even small 
amount of learning is measured by recurrent classroom tests. Only written-form examinations are an important mechanism for the identification of talent and a means of motivation for individual achievement. They have a strong influence on aims, content, teaching methodology and learning styles. Since the future of their students is in their hands, preparing them for the senior schools and universities by helping them score well on the national English examination must be the major focus of their teaching. These examinations are the crucial criterion of a student's academic future.

This pressures and nature of the traditional examination system and education pattern nurture the students' ways of learning English. Therefore, they commonly use the learning strategies that could prepare them for the discrete-point, structurally based English examinations. Student records in public examinations are treated by the community as the most important indicator of the quality of schools. Teachers and principals are rewarded according to how many students from each school succeed in the examinations and enroll at higher schools and universities. Such great social pressure pushes teachers to focus their attention on preparing their students for examinations. In reality, passing exams is the single most important aim of schooling, despite whatever is stated in the syllabus. Thus teaching and learning for exams become the "guiding principle" of school life.

Recently, English education in Libya has moved to the communicative language teaching (CLT) approach [3]. The underlying theoretical concept of CLT is communicative competence, which refers to the ability for language learners to use socially, contextually and culturally appropriate language in communicative contexts [4]. However, most Libyan learners of EFL have difficulties to develop their communicative competence beyond the classroom mainly because they do not have a supportive learning environment where they can hear and speak English for communicative purposes [5]. Therefore, some special efforts are needed to help Libyan students expand their language learning experiences and practice the target language outside the classroom. This need can be found in the Libyan government's special emphasis on English language proficiency and computer literacy in the spirit of globalization. English language proficiency and computer literacy are currently essential elements in the Libyan society in looking for a job, obtaining promotion and entering into a school of higher education [3]. In these circumstances, the technology, combined with a variety of computer-assisted language learning (CALL) programs, is on its way to restructuring the concept of the language classroom and the roles of the learner and the teacher in foreign language learning and teaching in Libya. The appropriate integration of technology into the language curriculum is a key issue to consider when examining the effective use of computer technologies for educational purposes in Libya.

\section{AdVANTAgES OF USING TECHNOLOGY IN LANGUAGE ClASSROOMS}

Several studies have documented the advantages of technology for language learning. These studies cover different aspects of learning as discussed in the following sections.

\section{A. Engagement}

Some researchers maintain that one of the benefits of technology use is an increase in student motivation [6], as fun and games are being brought into the classroom [7]. This fun factor is a key benefit in a language classroom [8]. Moreover, the novelty of the new technologies or learners' experience of those technologies in the classroom can enhance learners' engagement and motivation in fulfilling tasks. In addition, technology appears to improve language learners' academic ability. Reference [9] believes that Computer Assisted Language Learning (CALL) can do just this. This improvement is probably achieved by changing students' learning attitudes and boosting their self-confidence. Along this line, [10], [11] assert that the use of technology enhances learners' language proficiency and their overall academic skills.

\section{B. A Paradigm Shift in Teaching and Learning}

The advent of technology and development in the field of education has accelerated a shift from teacher-cantered to learner-cantered approaches in language learning and teaching. To meet the needs of digitally grown-up learners, teachers need to adopt a different role. They need to be facilitators, rather than the traditional bench-bound instructors, and they need to support and guide students' learning [7], [8]. Learning technologies support this important shift for the benefit of the learner.

\section{An Assessment Shift}

Incorporation of technology in the classroom enables learners to assess their own work in a more meaningful way, become better aware of the quality of their work and accept feedback more willingly. Moreover, it gives them a chance to undertake a more self-monitoring role, which leads to a higher chance of fulfilling tasks successfully. Teachers can also assess students' knowledge more accurately and objectively. The overall assessment shift from teacher to self and peer evaluation [4] contributes to the development of student autonomy which is emphasized in learning in the $21^{\text {st }}$ century.

\section{Collaborative Learning Enhancement}

Another benefit of technology use is the encouragement of collaboration and communication in learning activities. According to [7], new technology enables students to collect information and interact with resources, such as images and videos. Reference [5] states that the Internet can serve not only as a reference source but also as a means of communication. It is argued that technology enables the user to get connected to the world outside of the classroom and hence produce high-quality work, knowing that their work will be viewed by a large audience. In addition, learners can get in touch with their peers from other schools, experts in the field and members of interest groups.

\section{LITERATURE REVIEW}

Computer technology has changed every sphere of life [6]. It is useful not only for learners but also for teachers [7]. 
Recently, the use of technology for teaching is an integral part of successful teaching [8]. New technologies are influencing students' learning skills especially reading and writing [9].Teachers' perceptions about integration of technology in teaching have not got enough attention of researchers [10]. Teachers' beliefs about using technology affect their attitude to use technology for teaching and learning [11]. In Saudi Arabia English language teachers play very important role in teaching and learning [12]. In his quantitative and qualitative research study with Syrian high school English teachers, [13] found that teachers were worried about the devastating effect of technology in the form of internet and western cultural influence on Syrian culture. So, all the participants felt the need of locally created softwares and computer programs to teach English as a foreign language.

Many educational leaders and policy makers claim that computers and related internet technologies represent important educational innovations [14]. Recent studies have shown that the successful implementation of educational technologies depends largely on the attitudes of educators, who eventually determine how they are used in the classroom [13].

Teaching and learning a foreign language through technology has become a new trend in foreign language education all over the world [15]. Most foreign language teachers know very little about the effective use of technology in education [16]. In their study of the attitudes of teachers in three middle schools, [17] found that teachers' concerns have a significant influence on the use of computers in the classroom. A recent study conducted by [18] to identify the factors affecting teachers' use of technology concluded that teachers should be introduced to the types of computer technology and to aim at the usefulness and benefits of these resources in improving teaching and learning. In a related study, [19] examined some of the factors that affect the adoption and integration of Information Communication and Technologies (ICT) into teaching, the author concluded that teachers' feelings, knowledge and attitudes among other factors influence their use technology within their classrooms.

Reference [20] found that teachers' beliefs were based on dilemmas' and concerns. However, the teachers were willing to use technology in order to benefit from it and to help their students. In a recent study, [7] found that despite the lack of proper training English language teachers were willing to use technology for teaching. Some of them used some sort of technology to improve students' linguistic skills. Reference [21] found that teachers were familiar with technology. The participants described technology helpful to increase students' motivation and to improve students' learning. In their quantitative study with 100 Arab teachers, [8] found that teachers were integrating technology in their class activities. They used a variety of technology to promote learning among students. The only difference was the method of using technology among male and female teachers.

\section{RESEARCh DESIGN}

Reference [22] defined qualitative research as "a means for exploring and understanding the meaning individuals and groups ascribe to social or human problems." Researchers using qualitative research often study issues in their natural settings, intending to interpret phenomena in terms of the meaning that respondents give to researchers [23]. Some scholars, such as [24], mention that researchers cannot claim absolute truths when studying the behaviours and actions of humans. Therefore, qualitative research is an approach that seeks to explore hidden issues and give meaning to them, chiefly by asking questions about phenomena and gaining a better understanding about them through the responses given [25]. For this research study I relied on qualitative research approach for in depth understanding of English teachers' interests and concerns. This research study conducted in Misurata city, the third largest city in Libya.

\section{A. Participants}

The researcher has chosen fifteen Libyan English language teachers to participate. Three of them refused to participate in the research study due to their personal reasons. Twelve in-service teachers participated in this research. All of them have teaching qualification from recognised Libyan universities. They teach at secondary and high schools.

\section{B. Data Collection and Analysis}

Reference [26] stated that there are some ethical issues associated with educational research and obviously state the principles of ethics that should be followed by researchers including: Minimizing the risk of harm, getting informed consent, maximizing and protecting anonymity and confidentiality, and providing the right to withdraw. Reference [23] explained that ethics and interview had a strong relationship. Hence, researchers need to focus on ethical issues while interviewing participants and ethical issues should be undertaken from the start to the conclusion. Therefore, the researcher contacted all the participants and took informed consent from them. The researcher also told the participants in details about his own role as a researcher and about the purpose of the research. The participants were informed that they could stop participating in the study at any time. Participants were willing and were very enthusiastic to express their views. They were well awareof digital technology. They were also informed that their names would not be used in the research study.

Semi structured and structured interviews were used for data collection. Face to face interviews were conducted between May, Jun, and July 2014. All the interviews were recorded and saved. Their responses were also saved and printed on a paper. The data was coded and then the themes were written. To improve the accuracy the member check technique was used. After the themes were identified, the reports were e-mailed to the participants and they affirmed them within a week.

\section{FINDINGS AND DISCUSSION}

\section{A. Understanding of Technology}

One of our main interests in this study was to know the participants' understanding of technology and it was clear from their responses that all the participants were acquainted 
with modern technology. Whenever they talked about technology they meant digital technology. Of the twelve teachers, eleven teachers considered using the computer as indispensable and necessary in an era of modern technology. It appeared that they naturally accepted the use of technology as an undeniable part of instruction.

Technology is not just computers. T.V, VCR, data show, CDs and projectors and laptops are all types of technology (Teacher B)

It is natural to use computers in the classroom. Using technologies in the classroom has many benefits to teachers and students alike. It is helpful for increasing students' motivation with effective audio-visual materials. (Teacher F)

It is desirable to use the computer in the language classroom. A traditional Libyan classroom environment is very restricted and unnatural for language learning and teaching. However, it is possible for learners to experience more real situations in a technology-enhanced environment. (Teacher A)

\section{B. Use of Technology for Learning and Motivation}

I was keen to know about their use of technology in the classroom. Nine teachers referred to students' induced motivation as an advantage of computer-assisted instruction. Teacher $\mathrm{D}$, in particular, commented that the use of computers made the class more interesting and increased students' class participation.

Students are highly motivated to learn the English language with interest. I feel happy because my students look cheerful in class and they participate in activities very actively. (Teacher D)

When I use technology student enjoy it. It is very helpful to motivate students. (Teacher K)

My students always ask me if I am going to take them to the computer lab for their language class. They get very excited when I inform them that we are going to use the computers for a particular class. (Teacher $\mathrm{C}$ )

Although some of them (i.e., students) think using technology is just for fun and a kind of break from the rigid teacher-centred classroom, many students are in fact learning a lot through using computers. (Teacher A).

\section{Type of Technology}

Another important theme was the type of technology, which was being used in Misurata schools. All teachers indicated that technological aids such as CD-ROMs, audio CDs, DVDs and the Internet are helpful for the development of listening and reading skills. They said that the simultaneous presentation of sound and real images via the World Wide Web could make language input more comprehensible. For example:

I think that CALL is very effective in fostering listening and reading skills. On the Internet, students can access numerous listening and reading resources, information, materials and activities. (Teacher $\mathrm{C}$ )

When using CD-ROMs or the Internet, students can listen to the native speakers, watch video clips, pictures, animation or movies. Those audio-visual features appeal to young students these days. (Teacher G)

In Libya, English is a foreign language, so students do not have any exposure to authentic material. That is why I think CALL is great source for authentic listening and reading. (Teacher B).

\section{Cultural and Traditional Styles of Learning and Teaching}

Interviewees have been concerned about the students' reactions to the use of technology in the classroom. The justification for their concern is that the use of technology is in its infancy and its use requires a shift from traditional teaching approaches. If the shift is drastic and sudden and students perceive the experience negatively, they may resist such changes, which in turn will lead to poor academic performance. A representative statement is:

My students think that computers are for fun and not for learning. They are not used to it (Teacher B)

\section{E. Main Concerns}

Eight teachers considered teachers' lack of computer skills as an influential factor. They confessed that, because of their lack of computer knowledge and skills, much more time is required for creating teaching materials and resources.

I'm not competent in computer skills, so I have some difficulties in dealing with resources and activities obtained from the Internet. It takes much time to modify them to the level of my students. (Teacher C)

Teachers' lack of confidence in computer skills is a matter of concern. If a teacher doesn't know how to use a computer well in the classroom, he or she feels stressed and uncomfortable with using computers in front of a class. (Teacher G)

Five teachers mentioned a lack of computer facilities in schools as another inhibiting factor preventing them from using computers. They complained about the lack of funding. They made clear that whatever they brought to school many times to teach they brought it from their own pocket.

The computer facilities in my school are very old and not in good condition. So, they can't support any video clips. (Teacher C)

Personally, insufficient facilities discourage teachers from using technology. In my school, some computers are working slowly and need to be up-dated. (Teacher F)

It is a positive thing that these teachers have adequate knowledge of modern technology. They not only know digital technology but also use it. It is also note worthy that they are optimistic to use it in the future as well which supports [20] point of view that teachers were willing to use technology in the future. Most of the teachers find it useful for students which validates [7] statement that technology is beneficial for both. The teachers in this study have serious concerns. The scarcity of technology is a main issue which they all talked about. From the above discussions it is clear that English language teachers in Misurata city are willing to integrate technology into their classes but they need technology and proper training to use it.

\section{DISCUSSION OF RESUlTS}

The results of this study confirm several factors that had already been identified in prior research. Like the teachers in 
previous studies, the participants used technology because it motivated students and because it offered a different mode of presentation, while they were also hindered by a lack of access to equipment, a lack of professional support, and a lack of confidence in their computer skills. However, this study also brought out other factors that may be more specific to L2 teachers, such as the opportunities for authentic use of the target language and the level of linguistic difficulty of the materials, two factors that are very important to consider when dealing with L2 learners. Moreover, this study revealed the inability of several teachers to see the connection between computers and language teaching, a perspective that would not likely occur in other subjects such as math or science. However, the background of the teacher did not turn out to be as important in determining the use of technology as prior studies would suggest. The number of years of teaching experience, prior technological training, gender, and even age did not appear to have a major impact on determining whether or not a teacher would use computers in language teaching. In addition, this study goes one step further than prior ones by examining L2 teachers' perceptions of technology and technology-based language teaching. The teachers saw technology as a tool, as a means to enhance teaching and promote learning, not as an end in itself. They also tended to associate the term 'technology' with computers, which would perhaps explain why so many of the prior studies focused solely on computers. The main reasons for the teachers' decisions regarding technology seemed to depend on whether the teacher was personally convinced of the benefits of using technology for L2 instruction, a factor that is underemphasized in previous studies. Most of the reasons cited by the participants for using technology deal with how it can help their students learn the target language better, such as offering a variety of input and motivating students, while two of the four reasons given for not using computers reflect a lack of confidence in the advantages of computer-assisted instruction for students. Although time was cited as a factor, it was not in terms of the time needed to learn how to use technology, but rather in terms of the time required for selecting materials, suggesting that teachers would be willing to use technology more if they felt it were beneficial. Likewise, the availability of professional development opportunities and the attitudes of administrators did not necessarily play a role in influencing decisions, implying that personal beliefs were still the major factor. In fact, [7] found that intrinsic factors such as personality or philosophical beliefs might be determining the levels of use of film and video among his participants, rather than extrinsic factors such as equipment or media services. Research on teacher decision making indicates how important teacher beliefs are in determining what they do in the classroom [8], [9]. After all, 'teaching is realized only in teachers'; it is not something to be memorized and regurgitated [4]. The critical role played by teacher beliefs perhaps explains why, in the present study, there were cases of older teachers who were using computers and younger teachers who were not using them, as well as why previous correlational studies have been unable to come to any definitive conclusions.

The results of this study suggest that teachers' decisions regarding technology use are based not on fear but on personal convictions. The teachers who did not use computers in their teaching never cited fear of computers as a reason for not using them; some of the teachers spoke of a lack of confidence in their computer skills, but not of a complete resistance to computers. It is likely that if these teachers were to learn more about using computers and about integrating them into their teaching, they would be perfectly willing to use them. Similarly, the reasons given for using computers and other technologies reflected the teachers' beliefs in the benefits of these technologies for students, rather than an adoration of all things technological. No one felt that language teaching could not take place without technology, even among those who believed that their teaching should reflect the technology-based society we live in. It is not a love-hate situation, therefore, but one based on practical concerns and personal convictions.

\section{IMPLICATIONS OF THE STUDY}

The results of this study indicate that merely providing teachers with the equipment is not enough; rather, it is necessary to convince them of the benefits of using it in the classroom. A case in point is the teacher who had full access to a computer lab within her own department, yet never once went inside. Conversely, a number of teachers had little or no support for using technology, yet they still took the initiative to learn about it themselves because they saw its usefulness to their students. Moreover, training cannot be limited to the simple 'how-to' of technology; several teachers expressed a desire to learn not so much how the equipment works as how it can be effectively integrated into the curriculum

One way to persuade teachers of the benefits of technology in language teaching would be involve them in the implementation process. As long as teachers feel alienated from technology, they will not see its benefits for language teaching. Understanding what factors influence teachers' decisions on using technology is an important step in ensuring that institutions are not wasting already limited funds on equipment that no one uses.

\section{CONCLUSION}

As technology becomes more and more dominant in our everyday lives, it will continue to exert a constant pressure on education. Under this increasing pressure, it becomes even more necessary for all parties involved to step back and examine their motivations. At the moment, the general opinion seems to be focused negatively on teachers, who are considered unwilling to change, while no one has thought to criticize educational institutions for their hesitation. This study has sought to show that the unwilling of teachers is a misconception and that their decisions regarding technology use are not based on a resistance to or an adoration of technology, but rather on their beliefs about the benefits of the technology for their students. If teachers choose not to use the technology provided to them, it is not because they fear technology but, rather, because they are not convinced of its usefulness. This conclusion suggests that when technology is 
not used, it is not simply the fault of the teacher, as we tend to believe, but also the fault of the institutions who are overly hasty in purchasing the latest technological innovations without considering the needs of both teachers and students.

\section{FurThER RESEARCH AND RECOMMENDATIONS}

This study cannot be generalised to other cities of Libya. It is limited to Misurata region. In future studies, the effectiveness of technology for language learning would be helpful. My first recommendation is to provide modern technology in all schools in Misurata region. My second recommendation is to provide proper training to in-service teachers to use technology for languageteaching. Libyan Universities should offer a course at bachelor of education level to use technology for teaching. My third recommendation is to redesign English language curriculum at school level. In which all the four skills should have equal importance. Special attention should be paid to active skills as well. Proper softwares and computer programs should be prepared to teach these skills.

\section{REFERENCES}

[1] Z. Yong and G. A. Cziko, "Teacher adoption of technology: A perceptual control theory perspective," Journal of Technology and Teacher Education, vol. 9, no. 1 pp. 5-30, 2001.

[2] P. A. Ertmer, "Teacher pedagogical beliefs: The final frontier in our quest for technology integration?"Educational Technology Research and Development, vol. 53, no. 4, pp. 25-39, 2005.

[3] N. Sabitha, "The business of teaching English as a second language: A Libyan case study," Procedia-Social and Behavioural Sciences, vol. 70, pp. 1243-1253, 2013.

[4] S. J. Savignon, Communicative Competence: Theory and Practice, New York: McGraw Hill, 1997.

[5] O. S. Saad and S. Borg, "Intentions and realities in implementing communicative curriculum reform," System, vol. 37, no. 2, pp. 243-253, 2009.

[6] H. F. Odabasi, "Faculty use of technological resources in Turkey," Innovations in Education and Teaching International, vol. 37, no. 2, pp. 103-107, 2000.

[7] J. R. Hill and M. J. Hannafin, "Teaching and learning in digital environments: The resurgence of resource-based learning," Educational Technology Research and Development, vol. 49, no. 3, pp. 37-52, 2001

[8] S. Göktürk, "Perceptions of in-service teachers regarding technology integrated English language teaching," Turkish Online Journal of Qualitative Inquiry, vol. 3, no. 3, pp. 1-14, 2012.

[9] C. B. Andoh, "Factors influencing teachers' adoption and integration of information and communication technology into teaching: A review of the literature," International Journal of Education and Development using Information and Communication Technology, vol. 8, no. 1, pp. 136-155, 2012.
[10] I. A. Khan, "The teacher of English: Pedagogic relevance in Saudi Arabia," English Language Teaching, vol. 4, no. 2, pp. 112-120, 2011.

[11] A. G. Al-Mekhlafi, The Effect of Instructional Media on Learning Second Language Teaching Strategies by Pre-Service Teachers, Unpublished doctoral dissertation, Arizona State University, Tempe, 1999.

[12] M. Ewa, "Teachers, technology and change: English teachers' perspectives," Journal of Technology and Teacher Education, vol. 13, no. 1, pp. 5-24, 2005.

[13] B. Barrell, "Technology and change in Atlantic Canada's new secondary English language arts curriculum," English Education, vol. 29, no. 2, pp. 231-247, 1999.

[14] B. C. Bertram, "Literacy technologies: What stance should we take?" Journal of the Literacy Research, vol. 29, no. 2, pp. 289-309, 1997.

[15] A. G. Almekhlafi and F. A. Almeqdadi, "Teachers' perceptions of technology integration in the United Arab Emirates School Classrooms," Educational Technology and Society, vol. 13, no. 1, pp. $165-175,2010$.

[16] A. Albirini, "Teachers' attitudes toward information and communication technologies: The case of Syrian EFL teachers," Computers and Education, vol. 47, no. 4, pp. 373-398, 2006.

[17] A. Howley, L. Wood, and B. Hough, "Rural elementary school teachers' technology integration," Journal of Research in Rural Education, vol. 26, no. 9, pp. 1-13, 2011.

[18] J. Liu, "A survey of EFL learners' attitudes toward information and communication technologies," English Language Teaching, vol. 2, no. 4, pp. 101-106, 2009.

[19] M. V. Olphen, "Perspectives of foreign language pre-service teachers on the use of a Web-based instructional environment in a methods course," CALICO Journal, vol. 25, no. 1, pp. 91-109, 2007.

[20] N. Atkins and E. Vasu, "Measuring knowledge of technology usage and stages of concern about computing: A study of middle school teachers," Journal of Technology and Teacher Education, vol. 8, no. 4, pp. 279-302, 2000

[21] A. Gilakjani, "EFL teachers' beliefs toward using computer technology in English language teaching," Theory and Practice in Language Studies, vol. 2, no. 3, pp. 630-636, 2012.

[22] J. Creswell, Research Design. Qualitative, Quantitative and Mixed Methods Approaches, Thousand Oaks: Sage Publications, 2009.

[23] S. Kvale, Interviews: An introduction to qualitative research Interviewing, Los Angeles: SAGE, 2009.

[24] D. C. Phillips and N. C. Burbules, Post-positivism and Educational Research, Rowmanand Littlefield, 2000.

[25] J. A. Maxwell, Qualitative Research Design: An Interactive Approach, Sage Publications, Inc, 1996.

[26] K. R. Howe and M. S. Moses, "Ethics in educational research," Review of Research in Education, vol. 24, no. 1, pp. 21-59, 1999.

Ibrahim Abukhattala was born in Misurata, Libya. He obtained MA in applied linguistics from Concordia University Montreal, Canada, in 1998 and $\mathrm{PhD}$ in applied linguistics from McGill University Montreal, Canada, in 2004.

He is currently an associate professor in the Department of English, Faculty of Arts, University of Misurata. He was the dean of the Libyan Academy for graduate Studies in Misurata, Libya, 2011-2013. He also was the director of the language centre, University of Misurata, 2009-2011.

Dr. Abukhattala has published many articles in different educational and linguistic journals and has contributed to many international conferences on language and education. 